Ks. Kazimierz Panuś

Kraków

\title{
„Myśl Boża względem Polski”. Kaznodziejstwo abp. Józefa Teofila Teodorowicza
}

W polskiej tradycji kaznodziejskiej zwykło się mówić o wielkich mistrzach ambony, że są niczym ks. Piotr Skarga, że mają coś z jego mistrzostwa słowa. Oto - by przywołać dwa przykłady - o ks. Hieronimie Kajsiewiczu CR (1812-1873) pisał w „Przeglądzie Lwowskim” wybitny historyk literatury i krytyk Stanisław Tarnowski, iż „objawił się on jako kaznodzieja, jakiego w Polsce od czasów Skargi nie było"135. Z kolei działającego w Poznańskiem ks. Aleksego Prusinowskiego (1819-1872) w uznaniu dla jego talentu oratorskiego intelektualiści i pisarze nazwali „Wielkopolskim Skargą”. Józef Ignacy Kraszewski pisał wprost: „Złotoustym jesteś istotnie, Panie mój”136. Spośród kaznodziejów polskich pierwszej połowy XX wieku, ten najwyższej rangi komplement w powszechnym odczuciu przynależał do wybitnego oratora, społecznika, posła i senatora II Rzeczypospolitej - abp. Józefa Teofila Teodorowicza (1864-1938).

Jako kaznodzieja w pamięci potomnych zapisał się mowami patriotycznymi, znakomitymi konferencjami radiowymi oraz przenikającymi do głębi kazaniami pogrzebowymi.

\section{Charyzmatyczny kaznodzieja patriotyczny}

Abp Józef Teofil Teodorowicz był niezwykle cenionym mówcą. Przemawiał w kościołach Lwowa, Krakowa i Warszawy. Jego kazania ściągały elitę umysłową. Porywał słuchaczy talentem oratorskim, precyzyjnie wyrażaną myślą, pięknem języka. Jego polszczyzna ukształtowana na lekturach wieszczów natrodowych, których echa słychać często także w treści jego przemówień, zadecydowała o tym, że kazania te odznaczają się wyjątkową urodą. Cenił on głęboko to wszystko, co stanowiło o duszy narodu, co składało się na skarbnicę narodowych pamiątek, która pozwoliła Polakom przetrwać lata niewoli.

Arcybiskup Józef Teodorowicz był wielkim wychowawcą narodu. Często w ostatni dzień grudnia w ormiańskiej lwowskiej katedrze czynił w kazaniu wielki rachunek sumienia całemu społeczeństwu polskiemu; co roku prowadził też rekolekcje wielkopostne dla inteligencji. Był cenionym spowiednikiem i kierownikiem duchowym.

Najistotniejszą część spuścizny kaznodziejskiej abp. Teodorowicza stanowią mowy narodowe, w rodzaju uroczystych kazań patriotycznych, które wygłaszał z okazji rocznic

${ }^{135}$ K. Panuś, Wielcy mówcy Kościoła w Polsce, Kraków 2005, s. 279.

${ }^{136}$ Tenże, Mowa żałobna na nabożeństwie za duszę Adama Mickiewicza ks. Aleksego Prusinowskiego, MH, 2013, nr 276, s. 85. 
narodowych lub aktualnych ważnych wydarzeń w życiu Kościoła i Ojczyzny ${ }^{137}$. Kazania te, będące często natchnionymi improwizacjami, zostały wydane w tomie pt. Na przetomie. Przemówienia i kazania narodowe (Poznań 1923). Warto zwrócić uwagę na kilka z zamieszczonych tam tekstów.

Kazanie Programy narodowe wygłosił abp J. Teodorowicz w czasie nabożeństwa dziękczynnego po uwolnieniu Krakowa z rąk austriackich w 1918 r., gdy Warszawa była jeszcze w rękach wroga. W tych chwilach, gdy doświadczano już „pierwocin radości” z odrodzenia Polski po przeszło stuletniej niewoli, arcybiskup w „prastarej świątnicy grobów królewskich i pamiątek przeszłości” wzywał do dziękczynienia Bogu za to, że „prysły kajdany nałożone narodowi, że ziemie polskie, dotąd rozdzielone, zlewają się w jedno”. Jednocześnie stawiał donośne pytania: „Czy możemy z ręką na piersi szczerze tu przed grobami królewskimi powiedzieć, żeśmy w tak wielkiej chwili wszyscy zjednoczeni?" Kiedy bowiem byłe państwa zaborcze Niemcy i Austria potrafią się łączyć w obronie własnych spraw, z Polaków w tak historycznej i oczekiwanej chwili wypełzają stare wady, podziały i kłótnie. Do słuchaczy zgromadzonych w katedrze na Wawelu kaznodzieja apelował, by służyli Bogu prawdziwemu, a nie Baalowi, by wokół programu: „Służba Boża i służba ojczyźnie skupić wszystkie pierwiastki społeczne”138.

W kazaniu Misja Kościoła w Polsce, wygłoszonym w katedrze na Wawelu w czasie konferencji biskupów 29 V 1921 r., nakreślił abp Teodorowicz program pracy Kościoła w odrodzonej Rzeczypospolitej: „Myśmy strażnikami na wysokiej ustawionymi wieżycy, bo z wyżyn Kościoła, które hen, aż ku niebu, wysoko strzelają, my straż trzymamy i baczymy [...]. I obejmujemy okiem naszym z wyżyn wieżycy Kościoła Polskę całą; obejmujemy ją ze wschodu na zachód, z północy na południe i śledzimy pilnie, zali gdzie smugi ogniste jak płomienne węże nie wydobywają się na wierzch i nie zwiastują złowrogiego pożaru"139.

We wstępie kazania nawiązał do procesji biskupów - uczestników konferencji do grobów królewskich. Prochy wielkich synów narodu, którzy do niedawna wstydzili się za doprowadzenie do katastrofy rozbiorów, teraz cieszą z odrodzonej ojczyzny. „Te prochy i kości poruszyły się wszystkie - to się nam zdawało, że serca wielkie, królewskie serca mistrzów Narodu, prochy królów, prochy wielkich bohaterów odziały się, jak w widzeniu Ezechiela, w żyły i w krew, że powstały te cienie ze swych trumien, że się przyłączyły do naszego orszaku, że stanęły pośród nas. A wtedy, kiedyśmy już je żegnali, kiedyśmy wychodzili z tych grobowców i one chciały wynijść za nami... Ale nie... one raczej nas przyzywały ku sobie, one, które przez stulecie niewoli wołały ku nam: «Odejdźcie stąd, odejdźcie od nas!» Dzisiaj zawołały: «Przyjdźcie do nas, przybliżcie się do nas!»”140

137 Tenże, Wielcy mówcy katedry na Wawelu, Kraków 2008, s. 343.

${ }^{138} \mathrm{~J}$. Teodorowicz, Programy narodowe. Kazanie wygtoszone w katedrze krakowskiej w czasie nabożeństwa dziękczynnego po uwolnieniu Krakowa z rąk austriackich 1918 r., w: tenże, Na przełomie. Przemówienia i kazania narodowe, Poznań 1923, s. 165-177.

139 Tenże, Misja Kościoła w Polsce. Kazanie wygtoszone w katedrze na Wawelu w czasie zjazdu biskupów w Krakowie dnia 29 maja 1921 r., w: tenże, Na przełomie, s. 279.

140 Tamże, s. 267-268. 
Zdaniem abp. Teodorowicza, Kościół powinien ogarniać całokształt spraw narodowych i czuwać nad takim ich rozwojem, by wiodły kraj drogą prowadzącą do Boga. Drogę tę wyznaczył Chrystus. Stąd wynika konieczność takiego oddziaływania na społeczeństwo, by „ukształtować, urobić w was Chrystusa Jezusa, wyryć Go w waszych duszach i sercach, ożywić was Jego duchem, urobić was na podobieństwo Jego, a nie spocząć dopóty, dopóki jedno z Nim się nie staniecie przez zjednoczenie z Nim, oto jest nasze zadanie" ${ }^{\prime 141}$.

W słynnym kazaniu pt. Cud wskrzeszenia Polski, wygłoszonym we Lwowie w 1919 r. tuż po uzyskaniu niepodległości, powtarzają się wielokrotnie słowa: „Jesteśmy wolni!” Brzmią one radośnie, niczym dźwięk dzwonu w uroczystość Zmartwychwstania Pańskiego. Mowa ta nabrała szczególnej aktualności pod koniec XX stulecia. Kiedy bowiem runął system komunistyczny w 1989 r., wracano na nowo do natchnionego tekstu ormiańskiego hierarchy zawartego we wstępie tego wyjątkowego kazania: „Jesteśmy wolni! Słyszycie, najmilsi? Jesteśmy wolni! Gdzie są wrogowie nasi? Pokruszona ich moc i siła; nie masz ich. Gdzie są kajdany nasze? Odpadły. Wolni jesteśmy! Zwiastuje mi tę nowinę wesołą świat, ale i obwieszczamy ją sami sobie. Bo zżyło się ucho nasze z żałobnym dźwiękiem dzwonu niewoli; bo piły serca nasze z kielicha goryczy i trucizny tak długo, że sami nie wierzymy własnym słowom naszym, sami podejrzewamy usta nasze, gdy te wołają: wolni jesteśmy!"142

Radość z odzyskania niepodległości nie osłabiała bynajmniej troski abp. Teodorowicza o kształtowanie ducha narodu zgodnie z nakazami Ewangelii. Dowodzi tego treść Kazania sejmowego, jednego z najpiękniejszych tekstów w historii polskiej wymowy kościelnej, wygłoszonego 10 II 1919 r. w katedrze warszawskiej na otwarcie obrad pierwszego w odrodzonej Polsce Sejmu. Nabożeństwo uświetnił swą obecnością nuncjusz apostolski abp Achilles Ratti, późniejszy papież Pius XI, obecni byli biskupi polscy, jak również Naczelnik Państwa Józef Piłsudski. Ideą naczelną tego uroczystego kazania jest prawda, że posłowie chcą budować Polskę na miarę wielkich przodków, do czego potrzebne są jedność, ład i porządek ${ }^{143}$. Przywołując na wstępie pamięć o zmarłych bohaterach narodowych walczących o wolność, których kości rozrzucone są po całym świecie, niczym prorok Ezechiel kaznodzieja wołał: „Idziemy na pierwszy sejm polski! [...] Gdybym był zdolny wskrzesić zmarłych z grobów i kurhanów, gdybym był zdolny jak Ezechiel wywołać ich w długim korowodzie, gdybym był zdolny w kości ich tchnąć ducha i życie, o wtedy, wtedy ustanowiłbym ich przed wami i obwieściłbym nowinę $\mathrm{w}$ jednym prostym i krótkim słowie: idziemy na pierwszy sejm polski, idziemy, żeby go otworzyć, idziemy, żeby błogosławieństwo Boże dla niego uprosić" ${ }^{\prime 44}$.

Mocno dramatyzując Kazanie sejmowe, abp Teodorowicz stworzył scenę orszaku, rozrastającej się procesji złożonej z zesłańców, weteranów, przedstawicieli różnych

141 Tamże, s. 272.

142 J. Teodorowicz, Cud wskrzeszenia Polski, w: tenże, Na przełomie, s. 181.

${ }_{143}$ M. Piela, Udział duchowieństwa w polskim życiu politycznym w latach 1914-1924, Lublin 1994, s. 188.

${ }^{144} \mathrm{~J}$. Teodorowicz, Kazanie sejmowe wygtoszone w katedrze św. Jana $w$ Warszawie $z$ okazji otwarcia pierwszego sejmu polskiego, w: tenże, Na przełomie, s. 195. 
dzielnic i stanów, podążającej zewsząd do wolnej ojczyzny. Wizja pochodu pokoleń stanowi częsty motyw w ówczesnym kaznodziejstwie, ale ormiański hierarcha tworzył ją w iście mistrzowski sposób. Na kształt „apelu poległych” zwoływał wielkich bohaterów narodowych: „Powołałbym tych jeszcze, którzy pisali wielką Konstytucję, a następnie tych pierwszych wojowników za wolność Ojczyzny, którzy się porwali do walki z przemożną siłą ciemięzcy, aby potem gasnącym okiem żegnać nadzieję, iż go zwyciężą. Powołałbym tu przed oczy nasze kości tych Polaków, co później roznosili je na wszystkie świata części od Samosierry aż do północnych zimnych grobów w Rosji” ${ }^{145}$.

Kolejne segmenty wypowiedzi, otwierane zwrotem „powołałbym”, przywołują kapitał wartości, jaki przekazuje współczesnym przeszłość i podkreślają zasługi i poświęcenia „pracowników dla polskiej sprawy i jej męczenników”. Bilans przeszłości pozwala kaznodziei skierować wezwanie do posłów o wyostrzoną świadomość brzemienia odpowiedzialności, jaką nakłada na nich dziedzictwo przodków, którego nie wolno zaprzepaścić. Powie o tym wprost, gdy ponownie zaznaczy potrzebę odwołania się do narodowej tradycji: „A teraz jeszcze raz zwrócę się ku wywołanym z przeszłości duchom. Nie na to je wywołam, by obrady naszego sejmu miały się przemienić w jakieś tajemnicze rozmowy z nimi, ale po to je wzywam, ażebyśmy w nich widzieli przedstawicieli żywych i symbole dróg dla Polski”. Nastała bowiem pora budowania. „Więc wstańcie z grobów i budujcie z nami wespół Polskę, a raczej wy nam każcie ją budować, a budować taką szeroką i taką przestronną, abyście wy w jej panteonie wszyscy się pomieścili; albo więcej: byście za sobą do niej wprowadzili całe rzesze żyjących, którzy tę samą myśl przedstawiają co i wy"146.

Zebranym w katedrze warszawskiej słuchaczom abp Teodorowicz uświadamiał wielkie zobowiązania moralne zaciągnięte wobec tych, którzy walczyli, cierpieli i oddali życie za wolny i sprawiedliwy kraj. Apelował więc do sumień i serc posłów, by w podejmowaniu uchwał sejmowych kierowali się wyłącznie dobrem ogółu: „My nie chcemy już odtąd szukać naszych własnych korzyści, a chcemy i pragniemy szukać jedynie tylko dobra naszej ukochanej i drogiej ojczyzny"147. Hołd złożony przeszłości, poniesionej przez nią ofierze, dał podbudowę do epilogu, finalnego pouczenia, wzywającego do odpowiedzialności za przyszłość Polski. Podkreślał, że prawdziwie szczera miłość ojczyzny woła o równość i sprawiedliwość społeczną, o zgodę narodową, o pomoc dla braci umęczonych walką w oblężonym Lwowie, w Wilnie, w Poznańskiem i na Kresach zachodnich, na Śląsku. Jest to bój, na końcu którego każdy mógłby powiedzieć za Zbawicielem: „Consummatum est” (J 19,30), dokonało się dzieło wielkie ${ }^{148}$.

O stopniu miłości ormiańskiego arcybiskupa do Polski dowodzi również kazanie Obrona Lwowa, wygłoszone w katedrze ormiańskiej we Lwowie w roku 1919, podczas nabożeństwa dziękczynnego za oswobodzenie Lwowa w wojnie z Ukraińcami. Poddając

145 Tamże.

146 Tamże, s. 199.

147 Tamże, s. 204.

${ }^{148}$ K. Panuś, Zarys historii kaznodziejstwaw Kościele katolickim, cz. 2: Kaznodziejstwo w Polsce. Od oświecenia do XX wieku, Kraków 2001, s. 344. 
analizie sytuację, która doprowadziła do powstania Ukraińców przeciwko Polakom, zaznaczył, że był to owoc haniebnej polityki zaborców, ale jednocześnie zwracał uwagę agresorom, że: „nie wolno im było skrycie i znienacka ugodzić w twierdzę katolickiej i polskiej kultury, jaką był Lwów. Nie wolno nikomu, patrząc na kościół Mariacki, zawołać: wezmę sobie tę świątynię, gdyż przed wiekami grunt, na którym była wzniesiona, do kogoś z członków mojej rodziny należał. I jak dziś nikt nie sięgnie po Berlin, dlatego iż tam kiedyś słowiańskie były ziemie, tak nikt prawa nie ma sięgać po Lwów dlatego, iż kiedyś przed wiekami Ruś się tu rozciągała"149.

W kazaniu tym abp Teodorowicz złożył hołd Orlętom, młodym obrońcom Lwowa, walczącym „przy współudziale i kierownictwie jednego tylko męża [Czesława Mączyńskiego]. Nie damy Lwowa! - zawołała młodzież na pierwszą wieść o opanowaniu stolicy. Lecz po modlitwie i po ślubowaniach poczuła w sercach odpowiedź Bożą na swoje powołanie i ukrzepiona, przeduchowiona zakrzyknęła: Bóg tak chce!”150 Mówiąc o polskim proteście przeciwko krzywdzącym Ojczyznę układom brzeskim akcentował, że Lwów wydał męczenników, aby ich krew stała się zasiewem tym bujniejszego żywiołu polskiego: „Nieraz to tak było w dziejach naszych, iż w chwilach wielkich naród ratował się przez jedną szczęśliwą a śmiałą myśl, którą brał i czerpał z natchnienia Ducha Bożego"151.

W trudnej historii Polski abp Józef Teodorowicz odczytywał znaki jej misji dziejowej, posłannictwo wyznaczone jej przez Boga. Znamienne pod tym względem jest kazanie Cud nad Wisła, wygłoszone w katedrze warszawskiej podczas nabożeństwa dziękczynnego za ocalenie miasta i Polski w 1920 r. Dał w nim wyraz przekonaniu o tym, że „cud nad Wisłą" był zwycięstwem odniesionym w imię Boga, uproszonym żarliwą modlitwą i gorącą wiarą walczących Polaków. Porównał go też do cudu pod Częstochową: „Tu i tam czerń zalała Polskę; tu i tam od zdobycia jednego grodu losy Polski zawisły; tu i tam boje, i zwycięstwo uwieńczone zostały cudem Pańskim"152.

\section{Kaznodzieja radiowy}

W dorobku kaznodziejskim abp. J. Teodorowicza godne podkreślenia są także rekolekcje narodowe, jakie głosił na antenie radiowej przez sześć kolejnych niedziel Wielkiego Postu w 1938 r. „Galaktyka Marconiego”, czyli świat ze strukturą kształtowaną przez kulturę elektroniczną i informatyczną, otwierała nowe możliwości głoszenia orędzia ewangelicznego. Pierwszym z tych wynalazków było radio ${ }^{153}$. Należy przyznać, że

149 J. Teodorowicz, Obrona Lwowa. Kazanie wygłoszone w katedrze ormiańskiej we Lwowie w r. 1919, w czasie nabożeństwa dziękczynnego za oswobodzenie Lwowa od Ukraińców, w: tenże, Na przełomie, s. 208.

150 Tamże, s. 209.

151 Tamże, s. 210.

152 J. Teodorowicz, Cud nad Wista. Kazanie wypowiedziane w katedrze warszawskiej w 1920 r., podczas nabożeństwa dziękczynnego za oswobodzenie stolicy i kraju od najazdu bolszewickiego, w: tenże, Na przetomie, s. 254-255.

${ }^{153}$ Jak podkreśla autor przytoczonego niżej artykułu, głoszenie Słowa Bożego w radio spotkało się w Europie początkowo z dużą nieufnością. Obawiano się, że taka forma przekazu może narazić Słowo Boże na 
kaznodziejstwo polskie, jako jedno z pierwszych w Europie, uczyniło z radiofonii skuteczny środek ewangelizacji. Podczas gdy watykańską stację radiową otworzył Pius XI dopiero 12 II 1931 r., Polskie Radio już 3 V 1927 r. transmitowało z katedry poznańskiej Mszę św. i wygłoszone wówczas kazanie ${ }^{154}$. Troskę o kaznodziejstwo radiowe powierzono powołanej w tym celu do życia Komisji Audycji Religijnych. W porozumieniu z dyrekcją Polskiego Radia i Episkopatem Polski, wypracowała ona zasady kaznodziejstwa radiowego, które obowiązywały w latach 1927-1939155. Pośród innych form, w programie rocznym umieszczano pewne cykle przemówien. Taki charakter miały kazania rekolekcyjne głoszone w niedziele Wielkiego Postu. Przed II wojną światową wygłaszali je specjalnie zapraszani kaznodzieje: w r. 1934 - ks. Tadeusz Jachimowski, w r. 1935 ks. Bronisław Kulesza, w r. 1936 - późniejszy biskup łódzki ks. Michał Klepacz, w r. 1937 - ks. Jan Szmigielski, w r. 1938 - abp Józef Teodorowicz i w r. 1939 - późniejszy błogosławiony ks. Henryk Hlebowicz.

Abp Józef Teodorowicz głosił konferencje wielkopostne w dniach 6, 13, 20 i 27 III oraz 3 i 10 IV 1938 r. Za jego zgodą zostały one wydane drukiem w kwietniu 1938 r ${ }^{156}$. We wstępie do tej publikacji podkreślono, że konferencji tych „z wielką radością i pożytkiem słuchało katolickie społeczeństwo polskie". Tematem przewodnim tych rekolekcji narodowych była biblijna scena kuszenia Chrystusa. Rozważania o wewnętrznym życiu Zbawiciela, kaznodzieja łączył z właściwym sobie talentem $\mathrm{z}$ analizą problemów, przed którymi stanęła Polska i Europa. A było się czym martwić. W Konferencji III stwierdzał: „Dziś Austria padła”. W ten sposób skomentował włączenie Austrii do III Rzeszy (Anschluss), co miało miejsce 13 III 1938 r. Konferencję tę kaznodzieja głosił 20 marca, czyli dokładnie tydzień po owym wydarzeniu. Mówcę niepokoiły też „okropne zbrodnie na wyznawcach Chrystusa [...] w Hiszpanii", gdzie w latach 1936-1939 trwała wojna domowa między siłami Republiki Hiszpańskiej wspieranymi przez liberałów, komunistów,

profanację. Pierwszej próby dokonano w Paryżu 2 I 1927 r. Patronował jej arcybiskup paryski kard. Louis-Ernest Dubois, a kazanie przez radio wygłosił ks. Lhlande. Próba się udała, a decyzja kardynała zyskała uznanie wielu katolików francuskich. Odtąd coraz częściej wygłaszano kazania przez radio. Kościół szybko dostrzegł możliwości tego środka przekazu i włączył je w służbę Ewangelii. Pierwsza przemowa religijna w Paryżu wygłoszona przez radio, WKat., 4(1927), nr 5, s. 97.

${ }^{154}$ Jak podkreśla cytowany niżej autor, Msze św. i kazania transmitowano początkowo dzięki staraniom rozgłośni poznańskiej, później innych. Wysoki poziom artystyczny zapewniał transmisjom poznański chór archikatedralny pod dyrekcją ks. Wacława Gieburowskiego. W okresie międzywojennym transmitowano Msze św. z kazaniami z najważniejszych kościołów na terenie ówczesnej Rzeczypospolitej: z częstochowskiej kaplicy jasnogórskiej i z wileńskiej Ostrej Bramy, z katedry wawelskiej i z kościołów parafialnych. Transmitowano przebieg wielkich uroczystości religijnych, m.in. odpust ku czci św. Wojciecha w Gnieźnie, Mszę św. polową z Placu Zamkowego w Warszawie z okazji 400-lecia urodzin ks. Piotra Skargi, uroczystości związane z Kongresem Chrystusa Króla w Poznaniu w r. 1937, Mszę św. kanonizacyjną o. Andrzeja Boboli SJ z Rzymu 17 IV 1938 r. Każdy dzień rozpoczynano w Polskim Radio pieśnią religijną, a w miesiącu maju nadawano nabożeństwa majowe z odpowiednimi kazaniami maryjnymi. T. Jachimowski. Kaznodziejstwo radiowe, PHom., 13(1935), z. 1, s. 221.

155 Pracami komisji kierował z upoważnienia kard. Augusta Hlonda ówczesny prepozyt Kapituły Metropolitalnej w Poznaniu i kaznodzieja katedralny, a od 1930 r. biskup katowicki Stanisław Adamski (1875-1967).

156 J. Teodorowicz, Kuszenie Chrystusa. Wielkopostne konferencje radiowe, Kraków 1938. 
socjalistów i anarchistów, a prawicową opozycją tworzoną przez nacjonalistów, monarchistów, konserwatystów i faszystów. Republikanie w ciągu kilku pierwszych miesięcy walk zniszczyli ponad 2000 kościołów i zamordowali około 7000 księży, zakonników i kleryków ${ }^{157}$.

Bezpośrednie zagrożenia dla Polski abp Teodorowicz słusznie upatrywał w niepokojących przemianach dokonujących się u wschodniego i zachodniego sąsiada. „Ze Wschodu - stwierdzał w Konferencji III - uderza na nas fala rosyjskiego komunizmu, który, chociaż występuje już w swej brutalnej i okrutnej formie, to jednak próbuje jeszcze niejednokrotnie przybrać i przyodziać na się maskę przyjacielską. Szatan kusiciel przedzierzga się w anioła światłości i poczyna się wciskać do wszystkich organizacji, by w nich i przez nie szerzyć swoją rozkładową niszczycielską robotę".

W Niemczech niepokoił go rozwój ideologii nazistowskiej. W Konferencji III stwierdzał: „Nie pali się wprawdzie kościołów [...], ale za to poczyna się przemieniać kościoły w stare pogańskie świątynie. Nie strzela się do kapłanów, lecz zamyka się ich w więzieniu i paraliżuje się wszelki wpływ ich apostolstwa. Nie wydziera się oczu statuom świętych, nie niszczy się posągów Chrystusa, ale za to nawet w życiu kulturalnym zaciera się ślady ducha chrześcijańskiego". Ideologia nazistowska, ruch narodowosocjalistyczny i jego przywódca Adolf Hitler jawili się w tych rekolekcjach narodowych abp. Teodorowicza jako ideologia neopogańska oraz ubóstwienie wodza i państwa, która brutalnie manipuluje historią i aktywnie zwalcza chrześcijaństwo. „Z tekstów wielkich dzieł muzyka Bacha, Haendla i innych usuwa się ustępy zaczerpnięte z Pisma Świętego, a zastępuje się je poezjami na cześć władców ziemskich. W pewnej stolicy europejskiej na przedstawieniu «Tannhäusera», Elżbieta nie modli się już przed Matką Boską, lecz przed głazem kamiennym, mającym przypominać ołtarze starożytnych Germanów. Czyż inaczej napiętnować można taką nienawiść, jak ją napiętnował w swym orędziu jeden z biskupów niemieckich, który napisał: «Zerwał się szatan i szaleje»".

Konferencje radiowe dowodzą, jak bacznie abp J. Teodorowicz śledził życie w Polsce i dostrzegał zagrażające jej niebezpieczeństwa. Nawoływał do zwrócenia się ku Bogu i prawdziwej wolności. Wyczuwając wyraźnie, iż Polska stoi na progu nowej, ciężkiej próby dziejowej, wołał o sprawiedliwe rządy i poprawę warunków bytowych społeczeństwa.

Warto przypomnieć, iż wielkopostne konferencje radiowe abp. Teodorowicza (z wyjątkiem Konferencji V) zostały nagrane na płytach niemieckiej firmy Decelith stosowanych wówczas przez radiofonię i szczęśliwie przetrwały do naszych czasów. W roku 2007 staraniem Fundacji Kultury i Dziedzictwa Ormian Polskich zostały odtworzone i zapisane na ogólnodostępnej płycie CD. Nagrania kazań abp. J. Teodorowicza są

157 W 1937 r. sekretarz generalny Komunistycznej Partii Hiszpanii José Diaz przechwalał się, że „Hiszpania znacznie prześcignęła Sowiety w walce z Kościołem. W jej częściach, które są w naszych rękach, Kościół przestał już istnieć”. R. Aubert, Historia Kościoła od 1848 do czasów wspótczesnych, Warszawa 1985, s. 419420; A. Beevor, Walka o Hiszpanię 1936-1939. Pierwsze starcie totalitaryzmów, Kraków 2009, passim; P. Moa, Mity wojny domowej. Hiszpania 1936-1939, Warszawa 2012, passim. 
unikatowe w historii polskiej fonografii ${ }^{158}$. Bezcenna jest ich wartość dla historii polskiego kaznodziejstwa.

\section{Mówca pogrzebowy}

Na dorobek kaznodziejski abp. Józefa Teodorowicza składają się też mowy pogrzebowe. Wiele z nich wygłaszał nad trumną znanych powszechnie i zasłużonych osobistości lub w rocznice ich śmierci. Ale stawał też nad grobem zwykłego człowieka. Głosząc prawdy o śmierci i zmartwychwstaniu, unikał panegiryzmu oraz sztucznego eksponowania zasług zmarłego; jego ziemskie życie oceniał z perspektywy wartości nadprzyrodzonych, podkreślając wkład do wspólnego dobra, akcentował zasługi dla Kościoła, znamiona ducha chrześcijańskiego i patriotyzmu. Do najbardziej znanych mów pogrzebowych ormiańskiego hierarchy należą: Mowa na pogrzebie śp. Izaaka Isakowicza (Lwów 1905), Matka Marcelina Darowska. Mowa żałobna wypowiedziana podczas obrzędu pogrzebowego w Jazłowcu dnia 14 stycznia 1911 roku (Lwów 1911), Mowa żałobna wygłoszona w Krakowie 15 września przy zwłokach śp. o. Pawta Smolikowskiego (Warszawa 1926) oraz Wobec ideałów Sienkiewicza. Mowa na nabożeństwie żałobnym za duszé śp. Sienkiewicza w kościele Mariackim w Krakowie (Kraków 1917).

W tym ostatnim z wymienionych przemówieniu, kaznodzieja w niezwykle patetyczny sposób przywoływał przedśmiertne słowa pisarza. Były one jakby symbolicznym podsumowaniem życia Sienkiewicza i stanowiły przesłanie dla potomnych: „Jak jeden z jego bohaterów konał bohaterską i chrześcijańską śmiercią z wezwaniem Najśw[iętszej] Maryi Panny, podobnie i on umierał pełen pogody duszy i modlitwą błagalną do Najświętszej Panny. Odmawiał konając «Pod twoją obronę». I jeszcze raz od nieba zawrócił spojrzenie do ukochanej swej ziemi - i usta jego bez skargi, ale z bólem wyszeptały: «Boleśnie mi umierać, nie ujrzawszy wolnej ziemi Polski». Dwie miłości, Boga i Ojczyzny, co spowiły były całą jego duszę, zbiegły się obie jeszcze w godzinę śmierci, aby zaświadczyć, czym dusza jego cała żyła i czym tchnęła. I nie ujrzał już więcej tej ziemi".

Ten właśnie tekst mowy żałobnej wraz z przywołanymi wcześniej kazaniem Cud wskrzeszenia Polski i Kazaniem sejmowym należą - zdaniem Antoniego Bednarka - do ścisłego „kanonu klasyki oratorstwa polskiego”159

Mowy abp. Józefa Teodorowicza są doskonale skonstruowane, wykwintne stylistycznie, odznaczają się precyzyjnym tokiem wywodu i erudycyjną refleksyjnością; poświadczając czas wielkiego przełomu, wielokrotnie uwydatniają syntetyczne spojrzenie na specyfikę historii i kultury polskiej. Bliski jest im także wyważony patos chwili

158 S. Kruczkowski, A. Musiałowski, Unikatowe nagrania kazań Arcybiskupa na płytach bezpośredniego zapisu, w: Arcybiskup ormiański Józef Teodorowicz. Wybitny polski kapłan, kaznodzieja i mąż stanu, Warszawa 2007, s. 63-70.

159 A. Bednarek, Setnik oratorów polskich XIX i XX wieku, Lublin 2008, s. 307. 
dziejowej, widoczny najbardziej we wspomnianych wyżej, wielkich, o historycznym dziś znaczeniu, mowach narodowych ${ }^{160}$.

\section{4. „[...] powiedziałem właściwie jedno tylko kazanie"}

Praca nad odzyskaniem niepodległości Polski i walka o jej kształt stanowiły zawsze myśl przewodnią kaznodziejstwa abp. Józefa Teodorowicza. Najkrócej wyraził to on sam we wspomnianym już kazaniu Cud wskrzeszenia Polski: „Głosząc wam tyle różnych kazań, powiedziałem właściwie jedno tylko kazanie - kazanie o myśli Bożej względem Polski i w różnych zdarzeniach mówiłem wam tylko o jednym zdarzeniu, które przedstawiałem kolejno to na tle nocnych cieni, to w pierwszym brzasku świtu, to w świetle poranka, to jak dziś w pełnym słońcu południa. Wiecie, o jakim ja mówię zdarzeniu o zmartwychwstaniu Polski”.

Postać ormiańskiego arcybiskupa, który w latach niewoli narodowej podtrzymywał nadzieję narodu polskiego na zmartwychwstanie Ojcyzny, koił jego rany w czasie I wojny światowej i wskazywał drogi Boże, którymi winna kroczyć odrodzona Rzeczypospolita, godna jest najwyższego uznania. 
A4. Uniwersytet Papieski

Tfand Jana Pawła I 